\title{
Peran Modal Manusia Terhadap Nilai Produksi Industri Kecil
}

\author{
FATKHURAHMAN \\ Universitas Lancang Kuning \\ Jalan Yos Sudarso KM 8 Rumbai Pekanbaru Telp. (0761) 52581. \\ Email: fatkhurahman@unilak.ac.id
}

\begin{abstract}
The value of production becomes an expectation whose development becomes also the excitement of the managers of a business. Basically the progress and withdrawal of a business can also be seen from the value of the business produced by the business manager. There is a close relationship between the value of production and the existing human capital of business managers. This research proves that the existence of human capital both tangible and intangible gives a positive role towards the value of production produced by small industries. This study uses a case study research technique aimed at small business managers of pineapple chips processed in the Tambang sub-district of Kampar Riau regency, then the customers of the data are collected through interviews. Qualitative techniques show that there are several roles of human capital in increasing the value of small industrial production. These roles include: 1) thinking about the uniqueness of pineapple processed products needed by the market, 2) the role in making the product look attractive to buyers, 3) the role in calculating selling prices, 4) the role in managing the business so that it is sustainable.
\end{abstract}

Keywords: Human Capital, Production Value, Small Industry

Kabupaten Kampar merupakan salah satu kabupaten yang memiliki potensi sumber daya alam yang sangat besar. Mulai dari pertambagan, perkebunan, peternakan, perikanan dan yang tak kalah menariknya adalah potensi perkebuinan nenas.

Perkebunan nenas yang terdapat di Kabupaten Kampar didasarkan pada potensi lahan yang rawa-rawa atau juga dikenal dengan lahan basah atau juga disebut dengan dataran rendah bergambut. Daerah ini memang cocok sekali untuk budi daya nenas. Karena perkebunan nenas membutuhkan daerah yang lembab dengan kandungan air yang senantiasa siap mendukung pertumbuhan air tanaman nenas.

Kampar menjadi salah satu dari lima daerah penghasil nenas terbesar di Propinsi Riau. Menyaingi Kabupaten Rokan Hilir, kemudian Indragiri Hulu, Kabupaten Siak dan Kota Dumai. Kemudian juga pemerintah Propinsi Riau sudah menjadikan perkebunan nenas tersebut menjadi sebuah sentra industri kecil dan menengah.

Saat ini potensi perkebunan nenas di Kecamatan Tambang seluas 1.550 Ha dengan produksi rata-rata 780 ribu ton per tahunnya.
Khususnya di desa kualu sendiri yang menjadi basis perkebunan nenas memiliki $1.050 \mathrm{Ha}$ kebun nenas yang produktif.

Peningkatan produksi nenas di daerah tersebut memang sangat menggairahkan, namun perkembangan ini masih belum diiringi dengan perkembangan nilai yang seharusnya dirasakan oleh para petani nenas itu sendiri. Petani nenas masih belum mendapatkan nilai manfaat yang lebih baik dari perkebunan nenas yang mereka miliki. Harga nenas yang masih belum stabil seperti pada saat panen, harga nenas mengalami kejatuhan. Kemudian juga masalah lain yang dihadapi petani nenas, seperti masalah hama nenas dan juga masalah kebakaran lahan yang memang dirasakan sangat rawan.

Berbagai persoalan yang dihadapi oleh petani, memang tidak kalah pentingnya masalah tersebut mengarah pada permintaan pasar yang mereka rasakan. Menurut Soemarsono dalam Putra, R. E. (2012) bahwa nilai produksi merupakan bentuk jumlah secara kuantitas produksi yang dihasilkan oleh seorang pengelola usaha. Jumlah tersebut menjadikan acuan dasar dalam memperhitungkan berbagai perhitungan 
bisnis seperti masalah laba dan rugi bisnis, juga masalah banyak sedikitnya penggunaan dari tenaga kerja dan lainnya adalah masalah penggunaan modal. Modal di sini tidak saja modal yang berbentuk uang, namun modal manusia juga menjadi bagian penting dalam investasi dan juga merupakan upaya meningkatkan kemampuan berinovasi dalam menghasilkan produk olahan yang lebih baik dan diminati konsumen. Kemampuan modal manusia dalam menghasilkan produk sesuai dengan keinginan konsumen memberikan jalan terbaik dalam meningkatkan nilai produksi di masa depannya.

Diakui memang banyak faktor yang memang menjadi faktor determinan dalam meningkatkan nilai produksi sebuah usaha. Sebagaimana disampaikan oleh Subekti, M. A. (2007) dijelaksan bahwa upaya untuk meningkatkan mutu dari produk yang dihasilkan dan penggunaan teknologi memang menjadi sebuah upaya nyata. Dimana dengan membaiknya mutu produk akan meningkatkan upaya perbaikan dalam hal memenuhi kebutuhan dari konsumen. Konsep mengenai konsumen adalah raja dan juga konsumen banyak maunya menjadi sebuah tantangan baru bagi pebisnis dalam memenuhinya. Melalui upaya memahami keluhan konsumen akan menjadi solusi dari bagaimana pengusaha meningkatkan kualitas produk yang dihasilkan. Hal ini karena dengan meningkatnya kualitas produk akan menjadikan permintaan produk akan meningkat dan hal ini akan menaikkan nilai produksi. Selain mutu produk yang perlu ditingkatkan juga perlu adanya aplikasi teknologi yang modern. Teknologi menghasilkan produk dengan lebih cepat, kemudian produk juga dapat dihasilkan dengan lebih baik dan persaingan harga akan lebih bersaing. Harga dapat diterapkan dengan lebih murah. Kondisi ini akan membuat permintaan produk akan semakin meningkat karena pengelola usaha sudah dapat membuat produk lebih murah dengan kualitas lebih baik dengan proses produksi lebih efisien.

Hal serupa pula disampaikan oleh Iryadini, L., Sugianto, F., \& Sugianto, F. X.
(2011) bahwa beliau mengatakan modal, tenaga kerja dan juga bahan baku menjadi sebuah satu kesatuan fungsi produksi yang perlu mendapatkan perhatian serius. Namun tidak hanya masalah abstrak yang dilakukan seperti dengan tidak mengindahkan detail dari berbagai faktor tersebut. Seperti penggunaan modal, dimana modal tidak hanya berupa uang, namun modal di sini dapat dikaitkan dengan kemampuan pengelola usaha untuk berinvestasi dalam hal intangible aset yakni modal manusia. Kemampuan modal manusia ini tidak hanya berasal dari modal pengetahuan saja, namun modal intelektual dan juga modal emosional dari manusia yang mengelola usaha juga menjadi bagian tak terpisahkan dalam meningkatkan nilai produk sebagai bentuk permintaan dari produk yang dihasilkan.

Selain itu juga hal berbeda sedikit yang dikatakan oleh Kustiari, R. (2012) bahwa dalam upaya meningkatkan nilai produksi yakni dengan melakukan perbaikan tidak hanya berasal dari luar yang dikenal dengan faktor produksi, namun juga dari dalam yang dikenal dengan istilah faktor pengelola usahanya. Faktor dari dalam ini memberikan dampak jauh lebih besar bila dibandingkan dengan faktor dari luar seperti faktor modal, bahan baku dan juga tenaga kerja. Faktor internal apabila dikembangkan seperti melalui pendidikan, juga pelatihan dan pengalaman lapangan dengan studi banding akan menjadikan tambahan yang lebih unik dan kreatif melihat peluang dan tantangan masa kini dan juga masa depan.

Jadi dari pendapat tersebut dapat dijelakan bahwa faktor modal manusia atau juga disebut juga dengan faktor pengolah produksi industri kecil memiliki peran yang relatif besar dalam meningkatkan nilai produksi pada industri kecil itu sendiri. Nilai produksi yang semulanya merupakan jumlah secara kuantitatif, juga dapat dilihat dari nilai secara kualitatif, seperti bentuk kepuasan pelanggan dan juga bentuk loyalitas pelanggan dalam membeli produk yang dihasilkan oleh pengelola usaha. Nilai ini 
akan menjadi nilai tambah dari produksi itu sendiri.

Apabila dilihat dari pendapat Wajdi, M. F., \& Isa, M. (2014) bahwasanya dipastikan bahwa modal manusia memiliki pengaruh yang signifikan terhadap kinerja bidang pemasaran, hal ini menunjukkan bahwa adanya peran besar modal manusia dalam membuat hasil jual beli produk meningkat. Peningkatan pembelian yang dilakukan konsumen ini menjadi sebuah nilai yang diperoleh pengelola usaha dalam menghasilkan kinerja bisnis mereka. Bagaimana membangun modal manusia yang baik, bahwa indiaktor yang digunakan dilihat dari pengalaman yang diperoleh pengelola usaha dalam berusaha akan memberikan warna dalam berpikir kreatif. Selain itu juga, melalui kemampuan untuk bagaimana mewujudkan ide usaha yang dihasilkan juga menjadi bagian penting dalam upaya menjadikan produk terwujud. Juga berkenaan dengan kemampuan daripada pengelola dalam menghadapi persaingan pasar dan juga mencoba-coba produk yang dipikirkan pada konsumen dan terus mempelajari reaksi konsumen dalam mencoba produk yang dihasilkan tersebut. Upaya perbaikan terus menerus menjadikan pengelola memiliki jiwa wiausaha yang handal dan ini juga bagian dari faktor modal manusia dalam rangka meningkatkan nilai produksi.

Peningkatan nilai produksi dari sebuah usaha juga memberikan dampak secara makro dalam perekonomian. Dampak multiplayer terhadap peningkatan nilai tambah ini memberikan makna dalam sebuah pertumbuhan besar. Sebagaimana disampaikan oleh Prasetyo, P. E. (2008) bahwa dengan adanya peningkatan nilai produksi akan mendorong pertumbuhan ekonomi kawasan. Jadi perlu adanya upaya yang baik dalam mendorong perkembangan nilai tambah dari pihak yang berkuasa seperti pemerintah. Pemerintah harus memberikan dukungan seperti teknologi dan sarana infrastrukur dan juga fasilitas pendidikan dan pelatihan bagi para pengelola usaha. Dampak yang ditimbulkan dari penambahan nilai produksi ini tidak hanya pada bisnis itu sendiri secara mikro, juga perekonomian sebuah daerah secara makro akan berdampak.

Modal manusia dikembangkan oleh Davenport (1999) dan sebelumnya dibahas oleh Becker (1993) yang selanjutnya diuraikan oleh Salehudin, I. (2010) ianya menjelaskan bahwa pada mulanya adanya pandangan bahwa dilihat dari sudut pandang karyawan dalam sebuah perusahaan. Pandangan tersebut menjelaskan bahwa adanya anggapan bahwa karyawan tidak sekedar potensi sumber daya yang memiliki tenaga dan ketrampilan. Namun juga manusia memiliki pikiran, dimana modal manusia dari sisi pikiran ini akan membuat sebuah perusahaan menjadi berkembang dan menghasilkan nilai produksi sebagai bentuk nilai tambah yang baik. Upaya yang dilakukan oleh pengelola usaha tidak sebatas untuk memanfaatkan tenaga yang dimiliki tenaga kerja dan juga memanfaatkan ketrampilan dari mereka. Lebih dari itu upaya membuat karyawan lebih pintar dan menggunakan pikirannya itu juga perlu dilakukan oleh perusahaan. Memang dijelaskan bahwa bagaimana cara mengembangkan modal manusia tersebut, apakah biaya yang dikeluarkan untuk mengembangkan modal manusia itu menjadi tanggung jawab perusahaan dan juga seberapa besar dampak yang ditimbulkan dalam upaya mengembangka modal manusia tersebut. Hal ini semua menjadi sebuah pertanyaan yang harus dipertimbangkan dalam mengembangkan dan berinvestasi dalam modal manusia. Karyawan sebagai modal manusia dianggap dapat dikembangkan dan perusahaan perlu mengelola dengan baik agar manfaat dari penggunaan pikiran kreatif dari karyawan hasilnya dapat dinikmati oleh perusahaan. Memang dirasakan banyak masalah lain yahng timbul dengan adanya pengembangan modal manusia itu sendiri selain dari manfaat yang diharapkan, seperti masalah mudahnya karyawan berpindah ke tempat lain. Hal ini memang terjadi, karena modal manusia pada 
karyawan akan menjadi hal yang melekat pada karyawan dan karyawan akan dengan mudahnya untuk memanfaatkan modal yang dimiliki dalam rangka mendapatkan apa yang diinginkan seperti materi dan jabatan.

Masalah tersebut juga apabila dikaitkan dengan pengembangan modal manusia pada usaha produk olahan nenas memang berbeda, karena pengembangan modal manusia dari sisi pengelola usaha berbeda dengan pengembangan modal manusia dari sisi karyawan. Pengelola usaha memiliki kebebasan memilih untuk bagaimana mereka mendapatkan manfaat dari pengembangan sumber daya manusianya seperti dari hasil pengalaman, pengetahuan dan juga ketrampilan dalam rangka membangun nilai produksi. Apalagi dilihat dari sisi dengan adanya perdagangan bebas ASEAN yang akan dilakukan di masa depan, perdagangan kawasan yang begitu ketat dengan masuknya secara bebas pengelola usaha dari luar akan membuat pengelola dalam negeri mengalami kesulitan. Sebagaimana dijelaskan oleh Abdullah, $\mathrm{H}$. (2014) bahwa dengan adanya kebijakan pemerintah mengenai kawasan bebas perdagangan dan juga keluar masuknya tenaga kerja dan pengusaha akan membuat dunia usaha dalam negeri mengalami kendala. Pemerintah perlu bersikap cepat dalam menghadapi masalah tersebut, perlunya dukungan sarana dan prasarana khususnya dalam membangun modal manusia pengelola usaha dalam negeri. Pengembangan sektor ini akan membuat pengelola dalam negeri menjadi berdaya guna dan berhasil guna. Perlu adanya alokasi anggaran dalam investasi modal manusia, melalui pendidikan dan pelatihan juga pengembangan kewirausahaan akan membuat para pengelola usaha UMKM menjadi siap menghadapi tantangan global.

Sebagaimana dijelaskan oleh Liliani, A. (2012) pengembangan wirausahawan menjadi wirausahawan yang memiliki kreatifitas dan inovasi dan berani menghadapi berbagai resiko menjadikan sebuah bangsa menjadi kuat dan penuh dengan ide-ide yang membangun bangsa. Melalui penciptaan wirausahawan akan mampu menciptakan lapangan pekerjaan. Hal inilah yang dibutuhkan sebuah bangsa untuk maju dalam menghasilkan produk unggulannya.

Memang apabila dikaitkan dengan produk olahan dari bahan baku nenas membutuhkan pengelola yang penuh dengan kreatifitas dan inovasi, melihat pasar lebih luas dan tidak saja berorientasi pada pasar lokal, namun mengarah pada pasar nasional dan internasional. Sebagaimana dijelaskan oleh Amruloh, D. A. G. (2012) modal manusia sebagai karakteristik pengelola usaha apabila dikembangkan berdampak pada kinerja usaha yang pada gilirannya merupakan bagian dalam upaya meningkatkan nilai produksi.

Juga disampaikan oleh Wijaya, A. (2012) bahwa apabila sumber daya yang dimiliki oleh karyawan maupun pengelolanya dikembangkan dengan efektif dan efisien akan sangat membantu perusahaan dalam meningkatkan nilai produksi yang merupakan bagian dari kinerja usaha. Hal serupa juga dijelaskan oleh Damanik, D. (2013) bahwa pengembangan modal manusia menjadi sebuah tindakan investasi penting dalam perusahaan yang penuh dengan tantangan saat ini.

Berdasarkan uraian berkenaan dengan nilai produksi sebagai bentuk nilai tambah bagi pengelola usaha dan hal ini besar dipengaruhi oleh modal manusia atau dikenal dengan istilah human capital. Dampak pengembangan modal manusia ini sebagai bentuk investasi memberikan andil besar dalam rangka penggerakan sektor bisnis UMKM, dimana peran modal manusia dilihat dari sisi kemampuan manusia dalam menciptakan inovasi ide baru yang memang dibutuhkan oleh manusia lain. Selain itu juga dengan modal manusia ini pula mereka mampu untuk mewujudkan ide tersebut menjadi sebuah produk nyata yang nantinya akan berdampak pada pendapatan yang diperoleh dalam rangka menciptakan nilai produksi sebagai bentuk apresiasi dari nilai tambah sektor bisnis. 
Namun dalam kaitannya dengan modal manusia pada usaha produk olahan nenas yang dihasilkan masyarakat desa kualu kecamatan tambang apakah human kapital berperan dalam menciptakan nilai produksi atau nilai tambah dari apa yang mereka miliki. Karena hal ini penting dibicarakan sebab selama ini para petani perkebunan nenas dalam menghasilkan produk yang ditawarkan kepada konsumennya masih belum tampak tawaran nilai tambah yang mereka hasilkan. Selain itu juga selama ini pemerintah sudah memberikan fasilitas dalam rangka mendukung adanya tumbuh dan berkembangnya kreatifitas yang menghasilkan inovasi baru bagi dunia usaha yang bergerak di sektor perkebunan nenas ini.

\section{METODE}

Lokasi penelitian dilakukan di Desa Kualu Kecamatan Tambang Kabupaten Kampar, dipilihnya kawasan ini dikarenakan di daerah ini merupakan kawasan sentra perkebunan nenas, dimana nenas menjadi bahan baku produk olahan masyarakat dan unik karena tidak semua daerah memiliki keunikan produk tersebut dengan hasil yang besar.

Jenis penelitian yang diterapkan dalam penelitian ini adalah studi kasus, dimana kasus pengelola usaha nenas menjadi bagian penting untuk dibahas karena permasalahan pokoknya adalah pengelola usaha belum mendapatkan nilai produksi yang baik dan bahkan cenderung dalam kondisi yang tidak berubah padahal potensi yang dimiliki luar biasa. Sekaligus menjadi sumber data dalam penelitian ini.

Informan tidak hanya berasal dari pengelola usaha dengan bahan baku nenas, namun juga dari konsumen pembeli produk nenas yang berada disepanjang jalan di daerah Rimbo Panjang. Teknik pengumpulan data dengan menggunakan teknik wawancara, yakni dengan melakukan wawancara yang bersifat terbuka kepada informan berkenaan dengan modal manusia yang dimiliki key informan yakni pengelola produk olahan nenas dan juga konsumen sebagai pembeli produk dan melihat langsung bagaimana produk dihasilkan dan penikmat produk.

Sedangkan teknik analisis data yakni menggunakan teknik desktiptif kualitatif, yakni dengan membuat deskripsi temuan hasil penelitian dan membahasnya secara triangulasi yakni dengan melakukan cek and ricek dari temuan dibandingkan dengan teori dan juga partisipan dari key informan.

\section{HASIL}

Dari hasil wawancara yang dilakukan kepada informan dari pengelola usaha produk olahan berbahan baku nenas berisial "Sr", "Ad" dan juga "Br" mereka menjelaskan berkenaan dengan peran modal sosial yang dimiliki pengelola produk olahan nenas terhadap nilai produksi selama ini. Hasil wawancaranya menjelaskan bahwa dalam rangka melihat potensi besar nenas yang ada, maka pengelola selama ini hanya menjual nenas sebatas nenas glondongan, dimana hasil kebun mereka petik dan mereka ikat untuk dijual dipinggir jalan. Panenan yang dilakukan sesuai dengan kebutuhan dan kemampuan konsumen membeli, dimana walaupun nenas banyak dikebun yang sudah siap panen, mereka tidak akan memanennya sekaligus, mereka menyimpannya dipoho agar tetap bertahan lama. Hal ini dilakukan karena pertimbangan menjual produk dari hasil kebun berkualitas baik dan masih segar, selain itu juga tidak mengeluarkan banyak biaya dan tenaga.

Namun kondisi demikian membuat keuntungan yang diperoleh menjadi sangat kecil, karena sepanjang jalan Rimbo Panjang dimana mereka berjualan sudah berjejer produk yang sama. Lebih parahnya lagi pada saat pada masa panen raya, dimana nenas dikebun yang sudah siap panen melimpah maka harga akan sangat jatuh.

Pemilik kebun dan sekaligus pengelola kebun produk olahan nenas memutas otak untuk mengolah produk olahan agar bisa dimanfaatkan. Produk yang dihasilkan seperti membuat kripik nenas, selai nenas dan juga nenas yang sudah dikupas. Namun masalah lain juga muncul 
pada saat nenas diolah menjadi produk turunan seperti kripik nenas. Produksi kripik nenas memakan waktu lama, dan juga biaya yang relatif besar. Dibutuhkan bahan baku lain dan peralatan pembuat kripik yang memakan modal tidak sedikit. Setelah produk jadi, mereka dihadapkan pada kemasan dan juga tempat penjualan. Hal ini yang membuat petani dan sekaligus pengolah bahan baku nenas mengalami kendala. Hal yang sama juga pada produk selai nenas. Selain memakan waktu dan biaya yang lama untuk menghasilkan uang, kegiatan ini juga tidak sedikit berdampak pada kerugian.

Kemudian juga wawancara dilakukan kepada konsumen yang membeli produk olahan nenas yakni: "Nv" sebagai pembeli yang kebetulan lewat dijalan dan membeli untuk tujuan oleh-oleh. Mengatakan bahwa produk olahan nenas dilihat dari kemasan masih belum menarik dan juga dilihat dari harga memang masih tinggi. Masih tingginya harga jual produk olah nenas ini menurut penjual karena biaya produksi yang relatif tinggi. Sehingga harga pokok produksinya tinggi pula.

Juga wawancara kepada penampung yakni inisial "Rs" yang berkenaan dengan kondisi permintaan produk olahan nenas. Musim nenas memberikan rasa nenas yang berbeda, ada yang pada musim tertentu dengan kadar curah hujan tinggi rasa nenas menjadi kurang manis, sedangkan pada musim kemarau rasa nenas lebih manis, namun lebih sedikit panenannya. Kami sebagai penampung melihat bahwa nenas ini apabila dikupas dan dijual akan meningkatkan nilai produksi. Kami menjualnya dipinggir jalan sepanjang jalan di kota Pekanbaru. Dengan harga 10 ribu rupiah per bungkus kami dapat menjualnya dan hanya membutuhkan nenas 1 buah. Harga yang kami beli dikebun sebsar 2.500 rupiah dan kami mendapatkan untung 7.500 rupiah. Omzet penjualan kami mencapai 100 buah per harinya. Saat ini kami penapung menyebar hingga 50 orang.

Selain itu juga saudara "Js" membeli produk olahan nenas untuk oleh-oleh khas kampar. Sebagai seorang yang sering melewati Jalan Rimbo Panjang kami melihat banyak produk olahan nenas dan kami dapat melihat jumlah yang banyak dengan harga yang bersaing. Hal ini juga adanya turunan produk seperti kripik nenas dan selai nenas dan membuat kami tertarik untuk oleh-oleh. Dan banyak dari teman-teman yang bertanya dan memesan, kalau lewat rimbo panjang belikan kripik nenas ya. Hal inilah yang membuat saya tertarik membelinya, selain harga yang terjangkau, juga rasanya yang khas dan juga produk olahannya juga bisa dibeli ulang.

Dari beberapa jawaban dari informan tersebut, maka dapat ditarik beberapa temuan penelitian bahwa peran modal sosial dalam rangka meningkatkan nilai produksi produk olahan nenas sebagai bentuk industri kecil antara lain: 1) modal manusia yang dimiliki pengelola usaha yakni berperan dalam memikirkan keunikan produk olahan nenas yang dibutuhkan pasar, 2) juga mereka peran dalam membuat tampilan produk menarik pembeli, 3) berperan dalam memperhitungkan harga jual, dan 4) berperan dalam mengelola usaha agar berkesinambungan.

\section{PEMBAHASAN}

Berdasarkan hasil penelitian tersebut di atas, maka dapat didiskusikan berkaitan dengan temuan mengenai pengelola perlu berkreasi dalam menghasilkan prodk unik olahan nenas, kemudian berjuang dalam membuat kemasan produk menarik konsumen dan mampu memperhitungkan keuntungan usaha serta mampu membuat usaha tetap berkembang dan berkesinambungan.

\section{Peran dalam memikirkan keunikan produk olahan nenas yang dibutuhkan pasar}

Keterbatasan produk olahan nenas yang dihasilkan pengelola usaha saat ini, dimana produk yang sama dikembangkan 
dan masih belum memberikan nilai produk meingkat.

Simatupang, T. M. (2008) menjelaskan bahwa industri kreatif merupakan bagian dari pengembangan modal manusia dan hal ini diarahkan pada bagaimana seseorang mampu menciptakan produk baru sesuai dengan keinginan konsumen.

Upaya yang dilakukan dalam rangka menghasilkan produk unik dari olahan bahan baku nenas yakani dengan studi banding dengan melihat-lihat daerah lain dengan produk dari bahan baku lain. Hal ini akan memotivasi pengelola usaha untuk berpikir lebih produktif lagi. Selain itu juga perlu adanya event perlombaan makanan khas bahan baku nenas yang sebaiknya dilakukan pemerintah Kabupaten Kampar dalam rangka membangun kreasi makanan olahan bahan baku nenas.

Sebagaimana dijelaskan oleh Fitri, M., Yurisinthae, E., \& Dolorosa, E. (2014) bahwa kurangnya sentuhan teknologi tepat guna menyebabkan nilai produksi produk nenas rendah. Jadi dari pendapat tersebut, apabila adanya penerapan teknologi yang tepat guna maka akan mampu menghasilkan produk unik dan mendorong nilai produksi.

\section{Peran dalam membuat tampilan produk menarik pembeli}

Kemasan produk yang dihasilkan oleh pengelolan olahan produk nenas masih belum menarik dan membuat produk terkesan kurang diminati. Menurut Akrom, M. C. (2013) bahwa kemasan memiliki pengaruh yang besar terhadap konsumnen membeli.

Cenadi, C. S. (2004) sebuah kemasan sebagai pemicu konsumen untuk membeli. Kemasan yang baik adalah kemasan yang dapat membuat konsumen spontan melirik produk dan juga kemasan memiliki seni yang tidak mengaburkan produk itu sendiri dan memiliki desain yang modern sesuai dengan perkembangan zaman dan menggunakan bahan baku terbarukan.
Dari pendapat tersebut, maka akan lebih baik bila kemasan untuk produk olahan nenas itu dipikirkan oleh pengelola usaha dengan membuat konsumen spontan melirik misalnya dengan pewarnaan yang khas, dan keunikan produk tetap tampil diproduk dengan sentuhan teknologi modern kemasan dapat didesain dengan indah dan asli.

\section{Peran dalam memperhitungkan harga jual}

Perhitungan harga jual dan harga beli masih minim dimiliki oleh pengelola usaha, dimana pengelola usaha selama ini bertani nenas dan kurang paham mengenai perhitungan keuangannya. Menurut Hasyim, D. (2014) dengan penerapan manajemen keuangan yang baik, maka usaha akan dapat dikendalikan keuangannya dan pada akhirnya akan mampu memotivasi pengelola usaha untuk terus meningkatkan nilai produksinya.

Pengelolaan keuangan menjadi bagian menarik bagi pengelola usaha, dengan penerapan manajemen keuangan ini pengelola akan dapat melihat keuntungan yang diraihnya dan pada gilirannya nilai produksi akan meningkat.

\section{Peran dalam mengelola usaha agar berkesinambungan}

Usaha yang berkesinambungan dilakukan dalam rangka menjaga produk tetap ada, selagi kebun nenas masih ada dan belum berubah menjadi perumahan menurut petani nenas, maka kami akan tetap bertahan. Menurut Tedjasuksmana, B. (2014) memang diakui bahwa UMKM adalah sektor riil yang mampu bertahan dari terpaan krisis ekonomi.

Ini menunjukkan bahwa petani nenas dan sekaligus pengelola akan tetap bertahan untuk membudidayakan nenas dan sekaligus mengembangkan produk turunan nenas dan diwariskan secara turun temurun. 


\section{SIMPULAN}

Dari uraian berkenaan dengan masalah peran modal manusia dalam rangka meningkatkan nilai produksi pada industri kecil maka dapat disimpulkan ada beberapa peran yang menonjol modal manusia antara lain: 1) memikirkan keunikan produk olahan nenas yang dibutuhkan pasar, 2) peran dalam membuat tampilan produk menarik pembeli, 3) peran dalam memperhitungkan harga jual, 4) peran dalam mengelola usaha agar berkesinambungan.

\section{DAFTAR RUJUKAN}

Abdullah, H. (2014). Realokasi Kebijakan Fiskal: Implikasi Peningkatan Human Capital dan Pembangunan Infrastruktur terhadap Pertumbuhan Ekonomi dan Kesejahteraan Masyarakat. Jurnal Bina Praja: Journal of Home Affairs Governance, 6(2), 117-128.

Amruloh, D. A. G. (2012). Karakteristik Usaha dan Jiwa Wirausaha Terhadap Kinerja Usaha pada Usaha Mikro dan Kecil (UMK) Keramik Plered Purwakarta. Eqien: Jurnal Ekonomi dan Bisnis, 1(2), 41-56.

Akrom, M. C. (2013). Pengaruh kemasan, harga dan promosi terhadap proses keputusan pembelian konsumen kripik paru UMKM Sukorejo Kendal (Doctoral dissertation, Universitas Negeri Semarang).

Cenadi, C. S. (2004). Peranan desain kemasan dalam dunia pemasaran. Nirmana, 2(2).

Damanik, D. (2013). Pengembangan Sumber Daya Manusia Usaha Kecil dan Menengah.

Fitri, M., Yurisinthae, E., \& Dolorosa, E. (2014). Strategi Pengembangan
Agribisnis Nenas di Kabupaten Kubu Raya Kalimantan Barat. Jurnal Social Economic of Agriculture, 3(2).

Hasyim, D. (2014). Kualitas Manajemen Keuangan Usaha Mikro Kecil Menengah (Umkm)(Studi Kasus Pada Distribution Store (Distro) Di Kota Medan). JUPIIS: JURNAL PENDIDIKAN ILMU-ILMU SOSIAL, 5(2).

Iryadini, L., SUGIANTO, F., \& Sugianto, F. X. (2011). Analisis faktor produksi industri kecil kerupuk Kabupaten Kendal(Doctoral dissertation, Universitas Diponegoro).

Kustiari, R. (2012). Analisis Nilai Tambah dan Imbalan Jasa Faktor Produksi Pengolahan Hasil Pertanian. In Prosiding Seminar Nasional "Petani dan Pembangunan Pertanian (pp. 75-85).

Liliani, A. (2012). Pengaruh Human Capital Dan Perilaku Inovatifterhadap Motivasi Berwirausaha (Doctoral dissertation, UNIMED).

Prasetyo, P. E. (2008). The Quality of Growth: Peran Teknologi dan Investasi Human Capital Sebagai Pemacu Pertumbuhan Ekonomi Berkualitas. JEJAK: Jurnal Ekonomi dan Kebijakan, 1(1).

Putra, R. E. (2012). Pengaruh Nilai Investasi, Nilai Upah, dan Nilai Produksi Terhadap Penyerapan Tenaga Kerja Pada Industri Mebel di Kecamatan Pedurungan Kota Semarang. Economics Development Analysis Journal, 1(2).

Salehudin, I. (2010). Invest in Yourself: aplikasi konsep human capital dari sudut pandang 
karyawan. Manajemen Usahawan Indonesia, 39(6).

Subekti, M. A. (2007). Pengaruh Upah, Nilai Produksi, Nilai Investasi Terhadap Penyerapan tenaga Kerja Pada Industri Kecil genteng di Kabupaten Banjarnegara (Doctoral dissertation, Universitas Negeri Semarang).

Simatupang, T. M. (2008). Perkembangan Industri Kreatif. School of Business and Management of the Bandung Institute of Technology.

Tedjasuksmana, B. (2014). Potret UMKM Indonesia menghadapi masyarakat ekonomi ASEAN 2015.

Wajdi, M. F., \& Isa, M. (2014). Membangun Konsep Modal Manusia Yang Berperanan Dalam Kinerja Pemasaran Industri Kecil.

Wijaya, A. (2012). Pengaruh Kapasitas Produksi dan Mutu SDM terhadap Omzet Usaha dan Profit Usaha pada Usaha Kecil di Kota Samarinda. In Forum Ekonomi: Jurnal Ekonomi, Manajemen dan Akuntansi (Vol. 15, No. 2). Mulawarman University. 